\title{
Mathematics Determination of Single Tuition: Efforts to Achieve Good Governance
}

\author{
Edi Irawan, Basuki ${ }^{1}$, Agus Purnomo ${ }^{2}$, Luthfi Hadi Aminuddin ${ }^{3}$, Muh. Muhsin ${ }^{4}$ \\ IAIN Ponorogo, Jalan Pramuka No156, Ponorogo, Indonesia ${ }^{1,2,3,4}$
}

\{nawariide@iainponorogo ${ }^{1}$ \}

\begin{abstract}
Determination of new student tuition fees for new students needs to be done systematically and mathematically. Therefore, it is necessary to develop an instrument that can be used to determine it. This study aims to find a mathematical pattern of determining single tuition for new students. The development of the instrument was carried out using the five stages of ADDIE. The results of the development obtained eight parameters used to determine single tuition. The eight parameters are the ownership status of Indonesia Smart Card (KIP)/Jakarta Pintar Card (KJP)/Prosperous Family Card (KKS), electrical power, status and occupation of the father, mother's status and occupation, amount of father's income, amount of mother's income, average grade point average, and college choice. Each parameter has a mathematical stratification option. Each parameter is given weighting according to the level of needs of each. Then the value is recapitulated based on the score of each parameter multiplied by the weight. This final grade is used for ranking and determining the amount of single tuition. The development of a single tuition determination instrument is a form of justice, transparency, accountability, effective and efficient as an effort to realize good governance at IAIN Ponorogo.
\end{abstract}

Keywords: Accountability; Good Governance; Mathematics; Single Tuition; Transparency

\section{Introduction}

Single tuition is part of the single tuition fees borne by each student based on their economic capabilities [1]. The determination of the application of single tuition also applies to the State Islamic Religious College under the Ministry of Religion of the Republic of Indonesia [2]. This is the implementation of the mandate of Law Number 12 of 2012 concerning Higher Education, especially in article 88 [3]. At state universities under the Ministry of Education and Culture, the amount of a single tuition fee is determined by the Minister of Education and Culture. Whereas, state universities under the Ministry of Religion are determined by the Minister of Religion of the Republic of Indonesia. The amount of single tuition every year is constantly changing and adjusting according to the group's economic capacity. Finally, the Decree of the Minister of Religion of the Republic of Indonesia Number 1195 of 2019 concerning Single Tuition At the State Religious College in the Ministry of Religion Academic Year 2020-2021[4]. 
The application of single tuition is essentially intended to remove the tuition fee so that tuition fees to be paid by students are only done once in each semester [5]. This will make it easy for students to predict tuition expenses each semester without additional costs such as practicum, service learning and graduation [6]. With the application of single tuition will further open up the potential for access to higher education by disadvantaged groups of society. At least there is a policy that a minimum of 5\% of the lowest single tuition is for students from poor or disadvantaged families [4]. That is, a minimum of $5 \%$ of the total quota of new students at each state university is intended for students who come from disadvantaged families.

Furthermore, the determination of the amount of single tuition is determined by the Chancellor or Chairperson of each college [4]. There are at least two main aspects that are used as the basis for determining a single tuition fund borne by students, namely the economic ability of students and the economic ability of parents of students or other parties who finance it [2]. These two aspects then become the basis for determining a new student must pay with a single tuition group 1, 2, 3, 4, or 5. Determination of the amount of single tuition is not necessarily able to satisfy all parties so that it often causes various criticisms. This happens because there is a mismatch in the economic capabilities of students with the magnitude of a single tuition class. Students with low economic conditions get a high single tuition class. Conversely, students with high economic conditions actually get a low single tuition class [5]. Besides, the amount of single tuition is still burdensome for students [6].

Based on the description above, the purpose of this study is to develop instruments for the determination of single tuition for new students. The instrument was developed following existing regulations and carried out objectively, systematically and mathematically. The estuary is that the system for determining a single tuition fee is more straightforward, more transparent, objective and practical. This was done as a form of efforts to realize good governance [7].

\section{Methods}

This research is research development. This is in accordance with the definition of research and development as a research method used to produce and test the effectiveness of the product [8], not to test the theory [9]. Development is carried out using the ADDIE model. ADDIE stands for Analyze, Design, Develop, Implement, and Evaluate [10]. This model was chosen because of its practicality and relevance to the design and purpose of this study. The stages in this study are adjusted to the five stages of the ADDIE model [11] as follows:

a. Analyze, at this phase, a mapping of the importance of product development is carried out. The analysis is carried out on new product models that will be developed. Identifying products that fit the needs and objectives to be achieved. At this stage also must be able to answer the question of whether the product is able to overcome the existing problems and whether the product can be applied directly.

b. Design, in this phase, the conceptual design of a product is carried out to be developed in the next stage. The instructions for making the product must be written in detail.

c. Develop, in this phase, the product is made. The product developed must be in accordance with the designs that have been prepared previously.

d. Implement, in this phase, the product that has been developed is applied to the actual conditions. 
e. Evaluate, After the product is used, then in this phase evaluation of the product is developed.

\section{Results and Discussion}

\subsection{Results}

\section{a) Analyze}

At this phase, an analysis of various parameters must be used as a basis for determining a single tuition fee for a student. Referring to existing legal regulations, what should be a foothold in the economic ability of students and the economic ability of students' parents or other parties who finance [1], [2]. The first indicator that shows the economic capabilities of students is the ownership of the Smart Indonesia Card (KIP) and the Jakarta Smart Card (KJP). The assumption is that those who have KIP or KJP are indeed students who come from low-income families. Therefore, ownership of KIP and KJP is one of the documents that becomes a parameter in determining the single tuition for new students.

The next parameter is the financial ability of parents of students or other parties who finance it. Various indicators serve as benchmarks for the financial ability of students' parents. Among them is the ownership of the Prosperous Family Card (KKS), the type of parents 'work, the amount of the parents' income, and the electricity used. Furthermore, to anticipate the eventual similarity in the final score of the economic ability of students and parents of students, it is necessary to add other variables, namely the average report score or test results and the status of higher education choices.

The next step is the classification and stratification of each of these indicators. The aim is that the determination of the amount of single student tuition is based on the accumulation of total scores from various existing indicators. Each indicator is given a minimum score of 1 and a maximum of 10. A minimum score is given to students with high economic ability, while the maximum score is given to students with low economic ability.

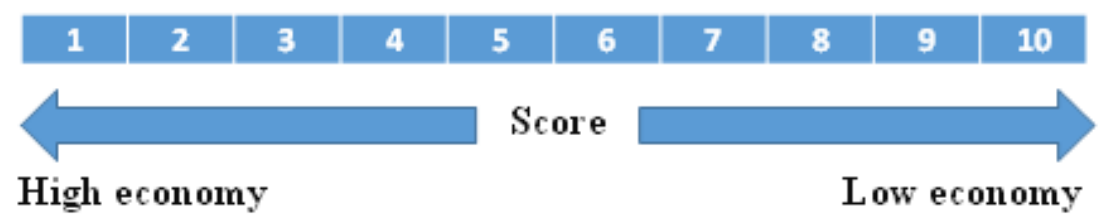

Fig. 1. Rules for Scoring Student Economic Capability

\section{b) Design}

At this stage, the classification design and scoring models are then carried out in each aspect. Scoring is done by referring to the principles as listed in Figure 1 above. The following is a description of the classification of each indicator and its scoring. First, ownership of KIP or KJP or KKS. This indicator only consists of two assessment classifications, which are either KIP or KJP or KKS or not. Students who have KIP or KJP or KKS and can show valid 
supporting data will be given the highest score, which is 10. In comparison, students who do not have KIP or KJP or KKS will be given the lowest score.

Table 1. KIP/KJP/PKH Classification and Reporting

\begin{tabular}{lc}
\hline KIP/KJP/KKS Indicator Classification & Score \\
\hline Have KIP/KJP/KKS & 10 \\
Do not have KIP/KJP/KKS & 1 \\
\hline
\end{tabular}

Second, the work of student fathers. In this indicator, classification is carried out in six occupational groups, namely 1) Entrepreneurs/Employees of BUMN/BUMD; 2) PNS/TNI/Polri; 3) Entrepreneurs/Village Officials/Teachers or Honorary/Non-permanent Employees; 4) Farmers/Fishermen/Builders/Drivers/Small Traders/Retail; 5) Farmers/Pedicab Workers/Parking Attendants/Building Coolers/Other Rough Workers, and 6) Died. Furthermore, each scoring group is listed as listed in Table 2.

Table 2. Classification and Scoring of Father's Work

\begin{tabular}{lc}
\hline \multicolumn{1}{c}{ Classification of father's occupational indicators } & Score \\
\hline Died & 10 \\
Farmers/Pedicab Workers/Parking Attendants/Building Coolers/Other Rough Workers & 9 \\
Farmers/Fishermen/Builders/Drivers/Small Traders/Retail & 7 \\
Entrepreneurs/Village Officials/Teachers or Honorary/Non-permanent Employees & 5 \\
PNS/TNI/Polri & 3 \\
Entrepreneurs/Employees of BUMN/BUMD & 1 \\
\hline
\end{tabular}

Third, the amount of student father's income per month. In this indicator, the classification is done in four father's income groups, namely 1) Income less than Rp. 1.000.000,00; 2) Earnings between Rp. 1.000.000,00 up to Rp. 2.000.000,00; 3) Income of more than Rp. 2.000.000,00 up to Rp. 5.000.000,00; 4) Income is more than income between Rp. $5.000 .000,00$. Then in each group, the amount of income is scaled as listed in Table 3.

Table 3. Classification and Big Scoring of Father's Income

\begin{tabular}{lc}
\hline \multicolumn{1}{c}{ Classification Indicator Big Father's income per month } & Score \\
\hline Income less than Rp. $1.000 .000,00$ & 10 \\
Earnings between Rp. $1.000 .000,00$ up to Rp. $2.000 .000,00$ & 7 \\
Income of more than Rp. $2.000 .000,00$ up to Rp. 5.000.000,00 & 3 \\
Income is more than income between Rp. 5.000.000,00 & 1 \\
\hline
\end{tabular}

Fourth, the work of student mothers. In this indicator, classification is carried out in six occupational groups of mothers, , namely 1) Entrepreneurs/Employees of BUMN/BUMD; 2) PNS/TNI/Polri; 3) Entrepreneurs/Village Officials/Teachers or Honorary/Non-permanent Employees; 4) Farmers/Fishermen/Builders/Drivers/Small Traders/Retail; 5) Farmers/Pedicab Workers/Parking Attendants/Building Coolers/Other Rough Workers, and 6) Died. Furthermore, each scoring group is listed as listed in Table 4.

Table 4. Classification and Scoring of Mather's Work

\begin{tabular}{lc}
\hline \multicolumn{1}{c}{ Classification of mather's occupational indicators } & Score \\
\hline Died & 10 \\
Farmers/Pedicab Workers/Parking Attendants/Building Coolers/Other Rough & 9 \\
Workers & 7 \\
Farmers/Fishermen/Builders/Drivers/Small Traders/Retail & \\
\hline
\end{tabular}




\begin{tabular}{lc}
\hline \multicolumn{1}{c}{ Classification of mather's occupational indicators } & Score \\
\hline Entrepreneurs/Village Officials/Teachers or Honorary/Non-permanent Employees & 5 \\
PNS/TNI/Polri & 3 \\
Entrepreneurs/Employees of BUMN/BUMD & 1 \\
\hline
\end{tabular}

Third, the amount of student mather's income per month. In this indicator, the classification is done in four mather's income groups, namely 1) Income less than Rp. $1.000 .000,00$; 2) Earnings between Rp. 1.000.000,00 up to Rp. 2.000.000,00; 3) Income of more than Rp. 2.000.000,00 up to Rp. 5.000.000,00; 4) Income is more than income between Rp. 5.000.000,00. Then in each group, the amount of income is scaled as listed in Table 5.

Table 5. Classification and Big Scoring of Mather's Income

\begin{tabular}{lc}
\hline \multicolumn{1}{c}{ Classification Indicator Big Mather's income per month } & Score \\
\hline Income less than Rp. $1.000 .000,00$ & 10 \\
Earnings between Rp. $1.000 .000,00$ up to Rp. $2.000 .000,00$ & 7 \\
Income of more than Rp. $2.000 .000,00$ up to Rp. 5.000.000,00 & 3 \\
Income is more than income between Rp. 5.000.000,00 & 1 \\
\hline
\end{tabular}

Sixth, the high electrical power of the parents' home of students. In this indicator, the classification is done in four groups of electric power, namely 1) not using electricity or not having electricity of their own; 2) electricity with 450 VA power; 3) electricity with $900 \mathrm{VA}$ power; 4) electricity with a power of 1350 VA or more. Furthermore, in each group, the electrical power amount of the student's parents' house was scaled as listed in Table 6.

Table 6. Classification and Reporting of Electric Power in Parents' Homes

\begin{tabular}{lc}
\hline \multicolumn{1}{c}{ Classification Indicators Electric Power Parents' Homes } & Score \\
\hline Not using electricity or not having electricity of their own & 10 \\
Electricity with 450 VA power & 7 \\
Electricity with 900 VA power & 3 \\
Electricity with a power of 1350 VA or more & 1 \\
\hline
\end{tabular}

Seventh, the average score of a student's exam results or report cards. The average score of a student's test results or report card is transformed on a scale of 1 to 10 using equations (1).

\section{$\underline{\text { Average Score }} \times 10$ \\ 100}

Eighth, choice of college. This indicator only consists of two classifications, namely first choice or second choice. Students who choose the first choice are given the highest score, which is 10 . While students who choose the second choice are given the lowest score.

Table 7. Higher Education Choices Classification and Scoring

\begin{tabular}{lc}
\hline \multicolumn{1}{c}{ Classification of Choice Indicators } & Score \\
\hline First choice & 10 \\
Second choice & 1 \\
\hline
\end{tabular}

Furthermore, each indicator is weighted according to the level of data accuracy as a basis for determining single tuition. The percentage of each indicator is listed in Table 8.

Table 8. Indicator and Weight Scores

Indicator $\quad$ Code $\quad$ Percentage




\begin{tabular}{lcc}
\hline KIP/KJP/PKH ownership & P1 & $30 \%$ \\
Father's occupation & P2 & $10 \%$ \\
Mather's occupation & P3 & $10 \%$ \\
Father's income & P4 & $10 \%$ \\
Mather's income & P5 & $10 \%$ \\
Home Electric Power & P6 & $5 \%$ \\
Average Report Score or Exam Results & P7 & $15 \%$ \\
College Choices & P8 & $5 \%$ \\
\hline
\end{tabular}

The next step is to do a mathematical recapitulation of the values as listed in equation (2) below.

$$
\begin{aligned}
\text { Total Score }= & (30 \% \times \text { Score P } 1)+(10 \% \times \text { Score P } 2)+(10 \% \times \text { Score P3 })+(10 \% \times \text { Score P4 })+ \\
& (10 \% \times \text { Score P } 5)+(5 \% \times \text { Score P6 })+(15 \% \times \text { Score P } 7)+(5 \% \times \text { Score P } 8)
\end{aligned}
$$

Then do the ranking of the total score. Students who have the highest number of scores will get the top rank. At the same time, students with the lowest score will get the lowest rank. The results of the ranking are used as a basis in determining students who receive the Indonesia Smart College Card (KIPK), group 1 single tuition, group 2 single tuition, group 3 single tuition, group 4 single tuition, and group 5. Single tuition with the top rank will be given KIPK according to the available quota. Furthermore, the ranking below is given a single tuition group 1 according to the available quota. And so on until the lowest ranked student will get a single tuition fee of 5 .

\section{c) Develop}

At this phase, the design of a single tuition fee is determined mathematically as outlined above. Development is carried out in two steps. First, the development of instruments in the form of forms containing various indicators above. In this study, the form was created using the Google Forms application. An example of how the form will appear is shown in Figure 2 below.
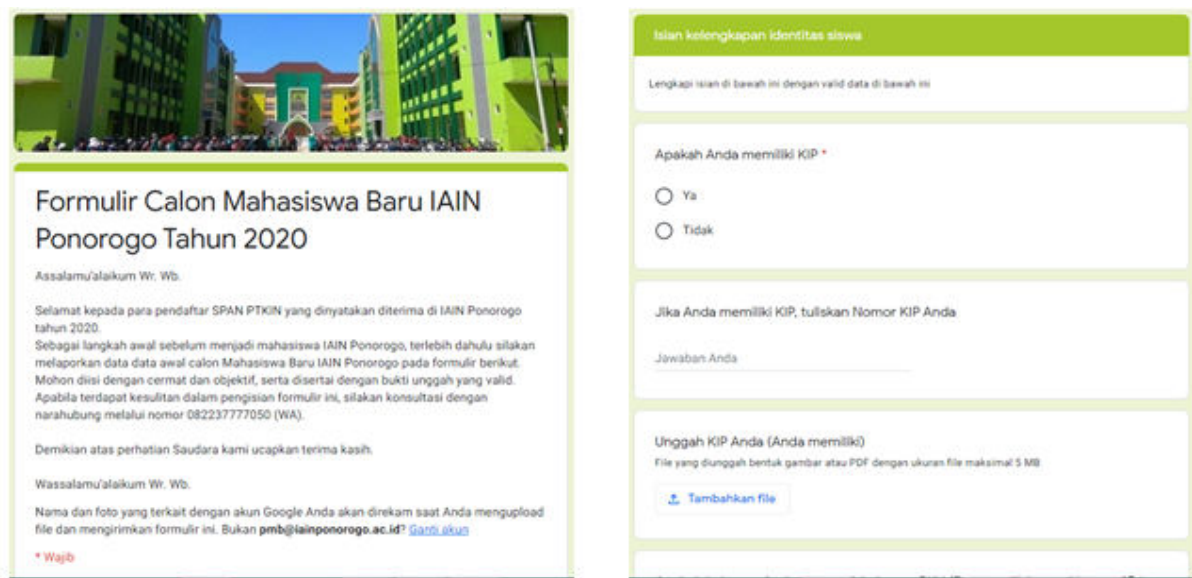

Fig. 2. Example Display of a Single Tuition Determination Instrument Form 
Secondly, data processing instruments were developed using Microsoft Excel applications. Some of the activities carried out using Microsoft Excel include the transformation of contents into a scale of 1 to 10, according to a previously designed design. In addition, Microsoft Excel is also used to do a recapitulation of grades, rankings, and determination of a single tuition group for each student.

\section{d) Implement}

After successful application development, the instrument was then used to determine the amount of single tuition for new students of IAIN Ponorogo who were accepted on the SPAN PTKIN academic year 2020/2021. A total of 1826 new students were assigned a single tuition group using the developed instrument. In accordance with the available quota, as many as 126 (7\%) students get KIPK, $111(6 \%)$ people get a single college tuition group 1, $182(10 \%)$ people get a single college tuition group 2, $844(46 \%)$ people get money single lecture group 3 , and the remaining $563(31 \%)$ people get a single tuition group 4 .

\section{e) Evaluation}

The use of the developed instrument was then carried out with the leaders and the admissions committee to conduct an evaluation conducted on April 20, 2020. Following are the results of the evaluation and recommendations for the determination of the single tuition instrument developed. First, equalization of status between students who have KIP, KJP and KKS. Students who have one or more of these cards have the same score. Second, it is necessary to limit the choice of content. The opportunity for students to fill out their own choices makes the conversion of grades more complicated, and some entries cannot be directly detected in the application. Third, it is necessary to add more detailed indicators including the condition of the parents' house, the number of family dependents, the amount of savings or accounts receivable, and ownership of motorized vehicles (motorbikes or cars). Fourth, the development of integrated website-based applications. Fifth, it is necessary to add an affidavit about the validity of the data filled in by knowing the local village office.

\subsection{Discussion}

The development of instruments using the ADDIE model has proven to be very useful and able to produce products according to needs. It is in line with the results of other development research which states that the ADDIE model is very effective [12], [13]. ADDIE was designed from the beginning for the development of the learning field [11], [14] has been proven effective in developing learning designs [15], [16], including to develop blended learning [17]-[19]. Besides, ADDIE is also useful for developing learning media [20]-[25] and also developing other applications [26], [27]. The results of this study reinforce the results of various previous research results that the five stages of ADDIE are very relevant for developing applications.

The development of mathematical instruments for determining single student tuition is in line with government programs to realize good governance [7]. Each student is given the same opportunity to provide detailed data. This shows the form of justice and transparency which is one indicator of good governance [28]. Determination of the amount of single tuition based on various parameters that have been filled out by the student. Therefore, the determination of this single tuition is done mathematically, transparently and accountably as one indicator of 
good governance [29]. Besides, the development of instruments that online provide convenience services for the user community so that it is more effective and efficient [28]. Fairness, transparency, accountability, effectiveness and efficiency are among the indicators of good governance [7], [28], [30].

\section{Conclusion}

Determination of a single student tuition group can be done mathematically following existing regulations. There are at least eight indicators that can be used as a basis for determining a single tuition fee, namely: KIP / KJP / PKH ownership, father's occupation, mother's occupation, father's income, maternal income, household electrical power, average report score or test results, and choice of college. This indicator can still be developed by adding other indicators such as the condition of parents' homes, the number of family dependents, the amount of savings or accounts receivable, and ownership of motorized vehicles. Each parameter is weighted following predetermined indicators. Mathematics plays a role in scoring, weighting, determining the number of scores, and ranking so that the process of determining a single student tuition group is more systematic. The development of a single tuition determination instrument is a form of justice, transparency, accountability, effective and efficient as an effort to realize good governance at IAIN Ponorogo.

\section{Acknowledgments}

Thank you to the Rector of IAIN Ponorogo and all the academics of IAIN Ponorogo, especially to the Committee for new student admissions.

\section{References}

[1] Menteri Pendidikan dan Kebudayaan RI, Permendikbud Nomor 55 Tahun 2013 tentang Biaya Kuliah Tunggal dan Uang Kuliah Tunggal Pada Perguruan Tinggi Negeri di Lingkungan Kementerian Pendidikan dan Kebudayaan. Indonesia, 2013.

[2] Direktorat Jenderal Pendidikan Islam, Surat Edaran Tentang Uang Kuliah Tunggal pada Perguruan Tinggi Agama Islam Negeri di Lingkungan Direktorat Jenderal Pendidikan Islam Kementerian Agama. Indonesia, 2013.

[3] Presiden Republik Indonesia, Undang-Undang Republik Indonesia Nomor 12 Tahun 2012 Tentang Pendidikan Tinggi. Indonesia, 2012.

[4] Menteri Agama RI, Keputusan Menteri Agama RI Nomor 1195 tahun 2019 tentang Uang Kuliah Tunggal Pada Perguruan Tinggi Keagamaan Negeri di Kementerian Agama Tahun Akademik 2020-2021. Indonesia, 2019.

[5] H. Hasanuddin, I. Ibrahim, and S. Syamsul, "Persepsi Mahasiswa Terhadap Implementasi Uang Kuliah Tunggal di Fakultas Ilmu Sosial Universitas Negeri Makassar," Universitas Negeri Makassar, 2019.

[6] P. N. Rambing, A. J. Rorong, and N. Palar, "Persepsi Mahasiswa Universitas Sam Ratulangi Tentang Kebijakan Uang Kuliah Tunggal,” J. Adm. Publik, vol. 3, no. 046, 2017.

[7] T. G. Weiss, "Governance, good governance and global governance: Conceptual and 
actual challenges," Third World Q., 2000.

[8] Sugiyono, Metode Penelitian Kuantitatif, Kualitatif dan R\&D. Bandung: Alfabeta, 2018.

[9] L. R. Gay, Educational Evaluation and Measurement: Competencies for Analysis and Application. Columbus: Merrill Publishing Company, 1985.

[10] T. Sutarti and E. Irawan, Kiat Sukses Meraih Hibah Penelitian Pengembangan. Yogyakarta: Deepublish, 2017.

[11] R. M. Branch, Instructional Design: The ADDIE Approach. Boston, MA: Springer US, 2009.

[12] K. Azimi and A. J. Rastegarpour, "A Survey of the Effectiveness of Instructional Design ADDIE and Multimedia on Learning Key Skills of Futsal," J. Educ. Manag. Stud., vol. 5, no. 3, pp. 180-186, 2015.

[13] U. Pendidikan et al., "Adaptation of ADDIE instructional model in developing educational website for language learning," Glob. J. Al-Thaqafah, vol. 8, no. 2, pp. $7-$ 16, 2018.

[14] R. K. Almomen, D. Kaufman, H. Alotaibi, N. A. Al-Rowais, M. Albeik, and S. M. Albattal, "Applying the ADDIE-Analysis, Design, Development, Implementation and Evaluation-Instructional Design Model to Continuing Professional Development for Primary Care Physicians in Saudi Arabia," Int. J. Clin. Med., vol. 07, no. 08, pp. 538546, 2016.

[15] M. Mayfield, "Creating training and development programs: Using the ADDIE method," Dev. Learn. Organ., vol. 25, no. 3, pp. 19-22, Apr. 2011.

[16] S. Danks, "The ADDIE Model: Designing, Evaluating Instructional Coach Effectiveness," ASQ Prim. Second. Educ. Br., vol. 4, no. 5, pp. 1-6, 2011.

[17] P. T. Anasi, "Rancangan Model Blended Learning Pada Mata Kuliah "Geografi Regional Indonesia' Untuk Mahasiswa Pendidikan Geografi,” J. Georafflesia Artik. Ilm. Pendidik. Geogr., vol. 4, no. 2, pp. 139-146, 2019.

[18] J. Friadi, Ganefri, Ridwan, R. Efendi, and G. John Friadi Ridwan , Raimon Efendi, "Development of Product Based Learning-Teaching Factory in the Disruption Era," Int. J. Adv. Sci. Technol., vol. 29, no. 06 SE-Articles, pp. 1887-1898, Apr. 2020.

[19] M. A. Ganefri, S. Zakir, J. Jama, and T. S. Wahyuni, "Using ADDIE instructional model to design blended project-based learning based on production approach," Int. J. Adv. Sci. Technol., vol. 29, no. 6, pp. 1899-1909, Apr. 2020.

[20] P. B. Herlandy, D. E. Ratna, and E. Ismanto, "Developing learning media with adobe flash in the subject of communication in network for X grade of vocational high school," CIRCUIT J. Ilm. Pendidik. Tek. Elektro, vol. 3, no. 1, pp. 29-40, 2019.

[21] A. Yusoff and S. Shafiril, "The development of 'forest ranger' as a 2D serious game application to increase awareness against illegal logging," Int. J. Innov. Creat. Chang., vol. 6, no. 2, pp. 148-163, 2019.

[22] T. N. Diyana, E. Supriana, and S. Kusairi, "Pengembangan multimedia interaktif topik prinsip Archimedes untuk mengoptimalkan student centered learning," J. Inov. Teknol. Pendidik., vol. 6, no. 2, pp. 171-182, 2020.

[23] R. A. H. Cahyadi, "Pengembangan Bahan Ajar Berbasis Addie Model," Halaqa Islam. Educ. J., vol. 3, no. 1, pp. 35-43, 2019.

[24] I. M. Tegeh and I. M. Kirna, "Pengembangan Bahan Ajar Metode Penelitian Pendidikan Dengan Addie Model," J. Ika, vol. 11, no. 1, pp. 12-26, 2013.

[25] E. Irawan, A. Ahmadi, A. Prianggono, A. D. Saputro, and M. S. Rachmandani, "YouTube Channel Development on Education: Virtual Learning Solutions during the 
Covid-19 Pandemic Institut Agama Islam Negeri Ponorogo, Indonesia Pasca Sarjana Institut Agama Islam Negeri Ponorogo, Indonesia," Int. J. Adv. Sci. Technol., vol. 29, no. 4, pp. 2469-2478, 2020.

[26] J. Marzal, Syamsurizal, E. Saputra, and P. E. P. Utomo, "The development of a trusted mechanism in building a web service to ensure the quality of data and information in the Universitas Jambi databorang application by using the ADDIE model," J. Phys. Conf. Ser., vol. 1516, no. 012003, pp. 1-10, 2020.

[27] E. Widyastuti and Susiana, "Using the ADDIE model to develop learning material for actuarial mathematics," J. Phys. Conf. Ser., vol. 1188, no. 012052, pp. 1-8, 2019.

[28] J. Graham, B. Amos, and T. Plumptre, "Principles for Good Governance in the 21st Century," Ottawa, 2003.

[29] V. P. Nanda, "The 'good governance' concept revisited," Ann. Am. Acad. Pol. Soc. Sci., vol. 603, pp. 269-283, 2006.

[30] R. V. Aguilera and A. Cuervo-Cazurra, "Codes of Good Governance Worldwide: What is the Trigger?," Organ. Stud., vol. 25, no. 3, pp. 415-443, 2004. 